\title{
PROFESI JURNALIS MUSLIM BERBASIS KINERJA
}

\author{
Muzakkir \\ Program Studi Ilmu Komunikasi, Universitas Teuku Umar \\ Email: muzakkir@utu.ac.id
}

\begin{abstract}
Abstrak
Studi dan analisis dalam tulisan ini di latar belakangi dengan menyikapi kinerja seorang jurnalis muslim dalam menjalankan pekerjaannya menyampaikan informasi kepada public. Jurnalis muslim sejati adalah seorang pejuang, seorang intelektual yang melakukan jihad fi sabilillah di medan perang, seorang pembaharu, penegak dan pembela kebenaran, pencerah pemikiran dan penoreh gagasan kepada ummat. Seorang jurnalis profesional ia memeliki jenjang karier yang bagus. Jenjang karier yang bagus itu pada hakikatnya telah diterapkan di semua perusahaan pers dimana si wartawan tersebut bekerja. Kinerja seorang jurnalis muslim harus terukur dengan baik, agar antara promosi dan sanksi dilakukan berdasarkan penilaian yang akurat dan akuntabel.
\end{abstract}

Kata Kunci: Profesi, Kinerja Jurnalis Muslim, Kejujuran dan Kebenaran

\section{PENDAHULUAN}

Seorang jurnalis (wartawan) profesional ia memeliki jenjang karier yang bagus. Jenjang karier yang bagus itu pada hakikatnya telah diterapkan di semua perusahaan pers dimana si wartawan tersebut bekerja. Kinerja seorang wartawan harus terukur dengan baik, agar antara promosi dan sanksi dilakukan berdasarkan penilaian yang akurat dan akuntabel. Seorang jurnalis muslim tentu tidak akan menceritakan secara detail keadaan seorang korban pembunuhan, yang disiksa dan mengalami nasib yang sangat memilukan di tangan pembunuh berdarah dingin jika dia sadar bahwa deskripsi tentang keadaan korban akan menyebabkan pembaca dihantui rasa takut, terganggu secara psikologis, atau tertusuk nurani kemanusiaannya

Jurnalis dinilai oleh perusahaan pers karena faktor kinerja dan prestasi. Ketika seorang wartawan mulai bekerja dengan status golongan rendah biasanya ia akan dibekali dengan tugas-tugas peliputan. Media tempat ia bekerja akan menilai kinerja wartawan tersebut sebagai dasar promosi mereka. Untuk mengapresiasi seorang wartawan, tentunya perusahaan pers tetap menggunakan beberapa aspek penilaian. Setiap perusahaan memiliki kreteria penilaian sendiri-sendiri. Tapi secara sederhana, perusahaan pers menggunakan dua asepek besar penilaian terhadap jurnalis yaitu teknik peliputan dan sikap. Salah satu aspek yang bisa memudahkan, penulis berusaha membahas tentang penilaian yang terkait dengan teknik peliputan terlebih dahulu.

Teknik peliputan. Ini merupakan aspek penting dalam hal meliput setiap peristiwa. Meskipun ada sebagian wartawan telah menempati pos atau sering disebut 'piket' yang ditetapkan oleh perusahaan pers masing-masing, namun wartawan juga perlu dibekali atau ditatar untuk membuat usulan berita lebih dahulu dari sekadar memberitakan kejadian.

Misalnya wartawan yang ngepos di Gedung DPR, seorang wartawan tentu melaporkan berita apa yang terjadi setiap saat di lembaga wakil rakyat itu. Namun, seorang wartawan tetap diharapkan dapat merancang suatu peliputan lebih baik dari standar yang 
sudah ada. Jika seorang wartawan yang meliput persidangan terhadap putusan (vonis) di Pengadilan Tipikor, itu tidak dianggap berkualitas. Seorang wartawan seharusnya punya gagasan tersendiri atau inisiatif untuk mengusulkan berita yang lebih ekslusif. Misalnya, seorang wartawan membuat usulan untuk wawancara mantan seorang narapidana yang baru saja bebas. Mantan napi dimaksud adalah seorang pejabat penting di negeri ini. Wawancara itu, tentunya untuk mengorek suatu kasus yang pernah ia lakukan secara detil dan mendalam.

Lalu muncul pertanyaan, mengapa harus membuat suatu usulan peliputan berita bagi wartawan?. Intinya, wartawan tidak semata-mata sebagai pencatat dari setiap kejadian di dunia ini. Wartawan juga sebagai insan yang harus melahirkan rancangan suatu berita. Berita merupakan sebuah gagasan yang harus dimunculkan dalam benak wartawan. Artinya, sebelum wartawan 'terjun' mencari berita, ia terlebih dahulu memikirkan ide-ide yang aktual untuk mendapatkan informasi. Wartawan harus terlatih melakukan perencanaan berita mengusulkannya kepada redaktur. Dengan begitu, wartawan dinilai aktif mencari dan mendapatkan informasi sampai melaporkan dalam tulisan. Hal yang menentukan adalah kualitas laporan. Dalam hal ini redaktur akan menilai laporan seorang jurnalis dari beberapa aspek yaitu:

\section{METODE PENELITIAN}

Penelitian yang penulis lakukan pada dasarnya bersifat literer (library research). Sumber data penelitian ini berdasarkan riset kepustakaan, dengan mengandalkan sumbersumber primer yang menyentuh pokok-pokok masalah seperti buku-buku jurnalistik, komunikasi, majalah, buletin-buletin. Sedangkan sumber sekunder berupa rujukan-rujukan lain yang berhubungan dengan penelitian dimaksud. Pendekatan yang digunakan dalam penelitian ini adalah pendekatan historis, dan multidisipliner. Setelah itu, data yang telah ada, penulis analisis dengan menggunakan metode komparatif dalam paradigm kualitatif. Tujuannya untuk mencari titik persamaan dan perbedaan para pakar jurnalistik sehingga dapat menghasilkan kesimpulan yang dapat dipertanggungjawabkan secara ilmiah.

\section{PEMBAHASAN}

\section{Profesi}

Profesi adalah kata serapan yang berasal dari bahasa inggris yaitu profess bermakna janji memenuhi kewajiban melakukan tugas khusus secara tetap/permanen, atau biasa disamakan dengan pekerjaan. Lalu apa bedanya profesi semisal dokter, pilot, dan wartawan jika dibandingkan dengan tukang tambal ban, supir, dan pembantu rumah tangga yang juga merupakan sebuah pekerjaan? Kata-kata inilah yang bisa menjadi inti pembeda antara profesi dan pekerjaan lainnya. Meski sama-sama membutuhkan keterampilan dalam masing-masing bidangnya, profesi membutuhkan kualifikasi tertentu sehingga pelaku profesi bisa disebut profesional.

Menjadi seorang yang profesional, diperlukan kualifikasi yang sudah ditentukan oleh masing-masing bidang. Kualifikasi tersebut berupa pendidikan khusus, ketrampilan khusus, standar kompetensi, masuk dalam organisasi, dan mengikuti kode etik. Selain itu, profesional bisa juga diartikan sebagai orang yang menggeluti sebuah profesi tertentu untuk menafkahi hidupnya. Seorang profesional sudah seharusnya memiliki sifat profesionalisme yang seringkali dianggap sebagai jiwa mereka. Profesionalisme menurut Kamus Besar 
Bahasa Indonesia (KBBI) adalah mutu, kualitas, dan tindak tanduk yang merupakan ciri suatu profesi atau orang yang profesional.

Sebagaimana yang diuraikan sebelumnya, seorang profesional harus tunduk kepada kode etik sebagai bahan kualifikasi yang disepakati dalam bidangnya. Demikian halnya dengan profesi jurnalis yang erat dengan Kode Etik Jurnalistik (KEJ) sebagai acuan moral bagi jurnalis. KEJ yang mengatur tindak tanduk jurnalis ini berbeda dari satu organisasi ke organisasi lain. Meskipun begitu, intinya kebenaran, independensi, akuntabel dan mengurangi dampak yang merugikan, wajib menjadi pertimbangan bagi seorang jurnalis dalam menulis berita. Dapat disimpulkan bahwa profesionalisme jurnalistik adalah kualitas jurnalis yang tunduk pada aturan yang tertera pada kode etik profesi. Oleh sebab itu jurnalis harus bisa menjalankan profesinya tanpa keluar dari koridor kode etik yang sudah ditentukan agar memiliki atribut profesional dan memiliki profesionalisme.

Kode etik dibuat oleh organisasi bidang profesi dengan maksud untuk mengarahkan anggota agar tidak keluar dari koridor profesionalnya. Adapun tujuan dari KEJ adalah agar jurnalis tidak perlu cemas jika muncul gugatan terkait tugasnya selama mematuhi KEJ. Jika masih diperkarakan, jurnalis bisa membela diri dengan bukti-bukti karya profesionalnya. Meskipun sudah melalui semua kualifikasi termasuk menaati kode etik hingga disebut profesional, seorang jurnalis tetap erat dengan konsekuensinya baik jurnalis yang berada di lapangan ataupun yang duduk di meja redaksi. Konsekuensi jurnalis pada hasil tulisannya harus balance dan bukan spekulasi atau opini yang dapat merugikan pihak lain bahkan medianya sendiri. Konsekuensi jurnalis tidak hanya dalam batasanbatasan kode etik, namun juga risiko yang kemungkinan terjadi saat peliputan atau dampak dari karya jurnalistik yang sudah dipublikasi. Wartawan yang 'terjun' langsung di lapangan disebut-sebut memiliki risiko paling tinggi bahkan hingga bisa membahayakan nyawa. Profesionalisme jurnalis tidak bisa ditawar-tawar lagi karena bisa menimbulkan efek besar jika dikesampingkan. Wartawan dan media pers bisa digugat oleh pihak yang merasa dirugikan oleh pemberitaan media tersebut. Namun dengan adanya kualifikasi dan uji kompetensi yang dilakukan oleh organisasi wartawan, diharapkan bisa memberikan perlindungan dengan menguji kemampuan profesionalnya. Bagian terpenting dari profesi jurnalis adalah bisa berkomunikasi dengan baik, dan mampu menjaga kode etik jurnalistik. Komunikasi yang baik perlu dilakukan oleh jurnalis agar tercapai komunikasi massa yang baik pula. Komunikasi massa adalah penyebaran informasi atau berita yang dilakukan kelompok sosial tertentu kepada khalayak yang heterogen serta tersebar di mana-mana. Dalam hal ini jurnalis melakukan komunikasi massa lewat media massa baik cetak ataupun elektronik. Perkembangan teknologi saat ini, memberikan kesempatan kepada siapapun yang bukan jurnalis untuk menyampaikan berita seperti halnya wartawan. Hal itu dikenal dengan sebutan citizen journalism atau jurnalisme warga. Tren jurnalisme warga berawal dari tragedi tsunami di Aceh tahun 26 Desember 2004 lalu. Saat itu, laporan berita dari korban tsunami ternyata bisa mengalahkan berita buatan jurnalisme profesional.

\section{Jurnalis}

Dalam kamus besar bahasa Indonesia, jurnalis diartikan orang yang pekerjaannya mengumpulkan dan menulis berita dalam surat kabar dsb, wartawan. Jurnalis adalah setiap orang yang berurusan dengan warta atau berita bisa disebut wartawan. Wartawan adalah orang yang melakukan pekerjaan kewartawanan yang berupa kegiatan/usaha yang sah berhubungan dengan perkumpulan, pengolahan, dan penyiaran dalam bentuk berita, pendapat, ulasan, gambar-gambar dan sebagainya dalam bidang komunikasi massa. 
Wartawan adalah orang-orang yang melakukan pekerjaan kewartawanan dalam surat kabar, majalah, radio, televisi maupun kantor berita. (Kurniawan Junaedhie: 1991).

Jurnalis (wartawan) adalah seorang yang melakukan jurnalisme yaitu orang yang secara teratur menuliskan berita (berupa laporan) dan tulisannya dikirimkan/dimuat di media massa secara teratur. Laporan itu dapat dipublikasi dalam media massa seperti surat kabar, majalah, televisi, radio, film dokumentasi, dan internet. Wartawan mencari berita/sumber untuk ditulis dalam laporannya; dan jurnalis diharapkan dapat menulis laporan yang paling objektif dan tidak memiliki pandangan subjektif dari sudut tertentu untuk melayani masyarakat. Istilah jurnalis baru muncul di Indonesia setelah masuknya pengaruh ilmu komunikasi yang cenderung berkiblat ke- Amerika Serikat. Istilah ini kemudian berimbas pada penamaan seputar posisi kewartawanan. Misalnya, "redaktur" menjadi "editor." (Wikipedia).

\section{Profesi Jurnalis Muslim}

Profesi jurnalis, menjadi profesi yang dicari oleh kalangan muda. Bukan saja mahasiswa lulusan komunikasi atau jurnalistik (broadcasting) tetapi juga dari jurusan lain yang berlomba-lomba menjadi jurnalis. Menjadi seorang jurnalis, 'kita dapat mengetahui peristiwa sekitar kita pertama kali'. Kita menjadi orang yang lebih aktual dibandingkan dengan masyarakat umum. Tetapi itulah tanggung jawab sebagai seorang jurnalis. Kita harus mengolah informasi yang kita dapatkan itu untuk diberikan kepada masyarakat yang menunggu informasi tersebut. Seorang jurnalis harus memiliki beberapa kemampuan dalam menuliskan dan menyampaikan sebuah berita. Hal ini sudah pasti akan didapatkan oleh mahasiswa yang kuliah di jurusan yang ada hubungannya seperti Ilmu Komunikasi. Tetapi, mahasiswa dari jurusan lain yang ingin menjadi jurnalis, mereka mendapatkan ilmu tentang jurnalistik dan sebagainya dari mana? Mereka hanya bermodalkan info-info yang mereka dapatkan dari teman-teman lain, ataupun bahkan mencari informasi dari internet. Asalkan mereka dapat dengan lancar mempromosikan dirinya saat interview kerja disebuah media, mereka pasti bisa saja menjadi seorang jurnalis. Sedangkan jurusannya yang memang sudah mengarah ke jurnalistik, tidak mendapat kesempatan itu karena sudah banyak direbut orang lain yang mendaftar duluan.

Jurnalis muslim sejati adalah seorang pejuang, seorang intelektual yang melakukan jihad fi sabilillah di medan perang, seorang pembaharu, penegak dan pembela kebenaran, pencerah pemikiran dan penoreh gagasan kepada ummat. Terkait sebagai pemikir dan penegak kebenaran, Rasulullah SAW memberikan petunjuk dan pedoman terhadap hasil karya tulis para jurnalis muslim. "Diakhirat nanti, tinta para intelektual muslim (ulama) akan ditimbang dengan bobot yang lebih berat dari pada darah para syuhada"

Jurnalis tidak hanya mampu mencari berita, tetapi juga harus dapat menulis dengan baik. Riset dan banyak membaca adalah jalan bagi seorang jurnalis unuk mengasah kemampuan menulisnya. Mungkin bagi sebagian orang, melihat profesi jurnalis akan mengatakan bahwa profesi yang tidak terlalu sulit. Tinggal duduk santai disuatu daerah, bertanya sana-sini, dan menjadikannya sebuah tulisan. Atau, tinggal duduk diam di kantor sambil bermain komputer, menunggu panggilan untuk terjun ke lapangan, berangkat, bertanya, dan menulis. Tetapi pada kenyataannya, tidak semudah itu dan tidak semudah yang diasumsikan orang. Butuh proses yang tidak singkat untuk bisa bertanya kepada seseorang. Karena tidak akan mudah mencari informasi dari seorang yang belum kita kenal sebelumnya, jika kita tidak menunjukkan identitas kita. Menuju tempat kejadian pun tidak 
segampang itu. Kita harus meminta ijin kepada pihak-pihak terkait untuk dapat melakukan peliputan. Apalagi jika kita sedang dalam kasus yang melibatkan polisi. Para polisi akan selektif dalam memilih siapa saja yang dapat mencari informasi tentang kejadian yang sedang berlangsung.

Ada beberapa kelebihan menjadi jurnalis yang dilansir oleh Ehow, diantaranya adalah: Bertualang Orang yang suka travelling sepertinya harus mempertimbangkan karir di bidang jurnalisme. Wartawan sering jalan-jalan atau berkeliling untuk mendapatkan berita. Anda memiliki kesempatan unutk mengunjungi tempat yang mungkin tidak pernah Anda datangi sebelumnya. Selain melakukan pekerjaan yang Anda senangi, yaitu meliput suatu peristiwa, Anda juga dapat sekalian berjalan-jalan ke tempat lain. Apalagi jika kita sebagai wartawan internasional. Keragaman Jurnalisme adalah bidang yang sangat beragam, di mana Anda melakoni berbagai bidang. Misalnya Anda awalnya adalah wartawan ekonomi, kemudian dipindah ke pos berita olahraga, kesehatan, politik atau gaya hidup. Tentu keragaman ini memperkaya hidup Anda. Jika Anda bosan dalam pekerjaan yang itu-itu saja dan tidak berkembang, jurnalis adalah karir yang tepat. Setiap pos berita memiliki tantangan dan kelebihan sendiri, sehingga wartawan harus terus beradaptasi dengan kondisi yang disajikan pada setiap waktu yang berbeda.

Demikian juga, wartawan harus mandiri dan, karena itu mereka menikmati banyak kebebasan dalam kegiatan sehari-hari. Bertemu orang penting tidak semua pekerjaan membuat Anda bisa bertemu Presiden, artis, musisi atau tokoh penting lainnya. Namun, jika Anda menjadi seorang jurnalis, segalanya menjadi mungkin. Anda bisa mewawancarai sejumlah tokoh penting dengan leluasa karena Anda punya akses dan punya identitas sebagai wartawan. Anda bisa datang ke berbagai seminar besar, konser musik dengan gratis karena profesi Anda untuk meliput dan menulis berita. Memberi wawasan pada masyarakat. Seorang jurnalis menyampaikan informasi kepada masyarakat umum dengan cara tersendiri dan tidak ditemukan dalam profesi lainnya. Wartawan tidak hanya menyebarkan informasi, mereka juga mengungkap informasi dan melakukan penelitian yang membawa fakta dan informasi aktual dan faktual. Sebuah karya jurnalis yang baik dapat bermanfaat bagi kepentingan umum. Anda berjasa menyebarkan fakta dan pengetahuan pada khalayak luas. Menjadi pribadi tangguh pekerjaan ini tampak berat dan penuh risiko. Sehingga tidak semua fresh graduate mau bekerja di bidang ini. Jurnalis dituntut untuk membongkar fakta dan mencari kebenaran. "Kewajiban pertama jurnalisme adalah pada kebenaran. Loyalitas pertama jurnalisme adalah kepada warga", kata Bill Kovach dan Tom Rosenstiel. ( Bill Kovach: 2004).

Jurnalis harus bertualang sampai menemukan fakta. Belum lagi tekanan deadline yang mengejar para jurnalis setiap harinya. Setiap profesi pasti memiliki keunggulan dan kelemahan. Begitu pula profesi jurnalis. Tidak semua orang bisa dengan mudah menjadi seorang jurnalis. Hanya orang-orang yang memang sudah memiliki kemampuan khusus di bidang ini yang dapat menjadi seorang jurnalis tangguh. Akan lebih baik lagi jika dia adalah seorang lulusan ilmu komunikasi, bukan dari jurusan lain yang tidak berkaitan dengan ilmu jurnalistik ataupun broadcasting. Nikson Siboro, "saya adalah saya dengan semua pemikiran saya".

\section{Basis Kinerja Jurnalis Muslim}

"Wahai orang-orang yang beriman, jika datang kepadamu orang fasik membawa berita, maka periksala dengan teliti, agar kamu tidak menimpakan suatu musibah kepada suatu kaum tanpa mengetahui keadaannya yang menyebabkan kamu menyesal atas perbuatanmu itu” (QS. Al-Hujarat: 6. 
Firman Allah SWT diatas adalah dalil yang cukup jelas mengenai penyikapan kita terhadap media massa yang ada disekitar kita sekarang ini. Sebagai umat sudah diberi bekal oleh Allah SWT berupa rules atau rambu-rambu dalam menyikapi fenomena-fenomena media sejak 14 abad yang lalu. Poin penting adalah jurnalis diperintah mengkroscek kebenaran dari berita tersebut. Tidak langsung percaya begitu saja. Tapi perlu tahu sampai perihal siapa yang membawa berita tersebut, dan informasi apa yang disampaikannya.

Ada sepuluh kewajiban jurnalis muslim dalam melaksanakan tugas jurnalitiknya:

Pertama, jurnalis (wartawan) muslim adalah hamba Allah yang kerena individu maupun profesi wajib menggunakan, menyampaikan dan memperjuangkan kebenaran di setiap tempat dan setiap saat dengan segala konsekuensinya. Hal ini sesuai dengan firman Allah SWT dalam al-Qur'an: (QS. Al-Nahl: 125)

Artinya: "Serulah (manusia) kepada jalan Tuhanmu dengan hikmah danpelajaran yang baik dan bantahlah mereka dengan cara yang baik. Sesungguhnya Tuhanmu Dialah yang lebih mengetahui tentang siapa yang tersesat dari jalan-Nya dan Dialah yang lebih mengetahui orang-orang yang mendapat petunjuk

Kedua, dalam menyampaikan informasi, wartawan muslim hendaknya melandasinya dengan itikad yang tinggi untuk senantiasa melakukan pengecekan kepada pihak-pihak yang bersangkutan sehingga tulisannya baik tentang pribadi dan khalayak tidak akan dirugikan. Seperti yang telah Allah ingatkan dalam firman-Nya:

Artinya; "Hai orang-orang yang beriman, jika datang kepadamu orang fasik membawa suatu berita, maka periksalah dengan teliti, agar kamu tidak menimpakan suatu musibah kepada suatu kaum tanpa mengetahui keadaannya yang menyebabkan kamu menyesal atas perbuatannya itu” (QS Al-Hujarat: 6 )

Ketiga, ketika menyampaikan berita/informasinya, wartawan muslim hendaknya menggunakan bahasa yang baik dan benar dalam gaya bahasa yang santun dan bijaksana. Tidak menggunakan kata-kata vulgar dan menjujung tinggi nilai-nilai kemanusiaan. Dengan demikian, apa yang disampaikannya akan dapat dimengerti, dirasakan, dan menjadi hikmat bagi khalayak.

Keempat, dalam menjalankan tugas jurnalistiknya, wartawan muslim hendaknya melaksanakan secara profesional dalam iklim kerja yang produktif sehingga karyanya akan memiliki hasil yang optimal untuk selanjutnya akan dipandang sebagai aset utama perusahaan. Firman Allah SWT dalam Al-Qur'an:

Artinya, "Sesungguhnya Allah SWT menyuruh kamu menyampaikan amanat kepada yang berhak menerimanya, dan menyuruh kamui apabila menetapkan hukum diantara manusia, supaya kamu menetapkan dengan adil.Sesungguhnya Allah SWT member pengajaran yang sebaik-baiknya kepadamu. Sesungguhnya Allah adalah Maha Mendengar lagi Maha Melihat"'(QS An-Nisa': 58)

Kelima, dalam melaksanakan tugas-tugasnya, wartawan muslim hendaknya menghindari sejauh mungkin prasangka buruk maupun pemikiran negatif sebelum menemukan kenyataan objektif berdasarkan pertimbangan yang adil dan berimbang dan diputuskan oleh pihak yang berwenang. Firman Allah SWT:

Artinya, "Hai orang-orang yang beriman, jauhilah kebanyakan dari prasangka, sesungguhnya sebagian prasangka itu adalah dosa dan janganlah kamu mencari-cari kesalahan orang lain dan janganlah sebagian kamu menggunjing sebagian yang lain. Sukakah salah seorang diantara kamu memakan daging saudaranya yang sudah mati? Maka tentulah kami merasa jijik kepadanya...." (QS Al-Hujarat: 12) 
Keenam, dalam kehidupan sehari-hari, wartawan muslim hendaknya senantiasa dilandasi etika Islam dan gemar melaksanakan aktifitas sosial yang bermanfaat bagi umat. Wartawan muslim sudah seharusnya selalu memperkaya wawasan keislamannya untuk meningkatkan amal ibadah sehari-hari. Allah SWT berfirman:

Artinya, "Dialah yang mengutus kepada kaum yang buta huruf seorang Rasul diantara mereka, yang membacakannya ayat-ayat-Nya kepada mereka, mensucikan mereka dan mengajarkan kepada mereka kitab dan hikmah (Al-sunnah). Dan sesungguhnya mereka sebelumnya benar-benar dalam kesesatan yang nyata" (QS Al-Jumu'ah: 2).

Ketujuh, dalam melaksanakan tugasnya, wartawan muslim hendaknya menjunjung tinggi azas kejujuran, kedisiplinan dan selalu menghindarkan diri dari hal-hal yang akan merusak profesionalisme dan nama baik perusahaannya. Komitmen yang tinggi seyogyanya diberikan pada profesionalisme dan bukan pada ikatan primordialisme yang sempit. Firman Allah SWT:

Artinya: "Hai manusia, sesungguhnya Kami menciptakan kamu dari seorang laki-laki dan seorang perempuan dan menjadikan kamu berbangsa-bangsa dan bersuku-suku supaya kamu saling kenal-mengenal.Sesungguhnya orang yang paling mulia diantara kamu di sisi Allah adalah orang yang peling bertakwa diantara kamu. Sesungguhnya Allah Maha Mengetahui lagi Maha Mengenal.” (QS Al-Hujarat: 13).

Kedelapan, dalam melaksanakan profesinya, wartawan muslim hendaknya senantiasa mempercepat persaudaraan sesama profesi berdasarkan prinsip-prinsip ukhwah Islamiyah tanpa harus meninggalkan azas kompetisi sehat yang menjadi tuntutan perusahaan modern. Allah SWT berfirman:

Artinya: "Berlomba-lombalah kamu (dalam berbuat) kebaikan. Dimana saja kamu berada pasti Allah akan mengumpulkan kamu sekalian (pada hari kiamat). Sesungguhnya Allah Maha Kuasa atas segala sesuatu.”(QS Al-Baqarah: 148).

Kesembilan, dalam melaksanakan tugasnya, wartawan muslim hendaknya menyadari betul bahwa akibat dari karyanya akan memiliki pengaruh yang luas terhadap khalayak. Karena itu, hendaknya semua kegiatan jurnalistiknya ditujukan untuk tujuantujuan yang konstruktif dalam rangka pendidikan dan penerangan umat. Firman Allah SWT:

Artinya: "(Al-Quran) ini adalah penerangan bagi seluruh manusia, dan petunjuk serta pelajaran bagi orang-orang yang bertakwa." (QS Ali Imran: 138).

Kesepuluh, dalam melaksanakan tugasnya, wartawan muslim hendaknya dengan penuh kesadaran memahami bahwa profesinya merupakan amanah Allah, amanah umat dan perusahaan. Karena itu, wartawan muslim hendaknya selalu siap mempertanggungjawabkan pekerjaannya kepada Allah, kepada umat dan perusahaannya.

Artinya: "Niscaya Allah memperbaiki bagimu amalan-amalanmu dan mengampuni bagimu dosa-dosamu. Dan barang siapa mentaati Allah dan Rasul-Nya, maka sesungguhnya ia telah mendapat kemenangan yang besar.” (QS. Al-Ahzab: 71). 


\section{Kejujuran dan Kebenaran}

Profesi jurnalis muslim sangatlah penting soal kejujuran dalam menginformasikan kebenaran. Jika orang fasik, orang munafik memegang kendali di kalangan jurnalis pada media massa, sangatlah besar potensi dan peluang bagi mereka membelokkan dan menyingkirkan kebenaran dan kejujuran. Beberapa kasus dan fakta akan dengan mudah diplesetkan dan dimanipulasi, bahkan bisa dihilangkan hanya untuk kepentingan kelompok atau untuk kepentingan politik. Lalu timbul pertanyaan, bagaimana seandainya jika publik dapat mengkomsumsikan suatu kebohongan dari fakta yang sesungguhnya. Bagaimana jika mayoritas Islam di Indonesia ini menerima mentah-mentah informasi berita diberbagai media publikasi setiap saat, setiap hari?

Islam menegaskan, jika kita mau menilik kembali, betapa luar biasanya para imam mujtahid, ahli hadits, ahli ilmu fiqh, ahli ilmu falak, ahli ilmu antropologi dalam menyaring, mengumpulkan dan menyeleksi hadits-hadits tersebut. Setelah diseleksi, ternyata hadits itu memiliki beragam kriteria yang berbeda-beda, yang pada akhirnya hadits tersebut bisa dikelompokkan dan dikatagorikan menjadi hadits shahih, hasan, dhaif, maudhu`. Begitu telitinya, para imam mujtahid itu dalam meriwayatkan hadits. Pernah Imam Bukhari menempuh suatu perjalanan untuk menemui seseorang yang dikhabarkan dia meriwayatkan hadits. Ketika sampai pada tempat yang dituju, Iman Bukhari melihat orang tersebut sedang memanggil kudanya dengan cara melambaikan tempat makanan kuda yang kosong seakan-akan kuda tersebut akan diberi makan. Orang tersebut melakukan hal itu untuk menipu kuda itu supaya mau memenuhi panggilannya.

Apa yang dilakukan oleh Imam Bukhari? Melihat hal tersebut, Imam Bukhari langsung saja meninggalkannya. Hal itu, dilakukan karena ketatnya kriteria kredibilitas sebuah kejujuran seseorang dalam membawa hadits. Di zaman modern ni, kalau mau jujur tidak satupun jurnalis yang mampu memiliki kredibilitas seperti itu. Namun, paling tidaktidak boleh ada jurnalis muslim yang melakukan rekayasa terhadap kebenaran. Itu saja sebenarnya belum cukup, masih perlu juga diantara media-media yang ternama dan bonafit memiliki para jurnalis yang memegang teguh prinsip keimanan dan ketakwaan. Ada semangat jihad yang menggelora untuk menyampaikan apa yang disebut kebenaran. Tanpa rekayasa. Tanpa kepentingan. Tanpa kepentingan politik tertentu. Tanpa niat lain selain karena Allah SWT menyuruhnya berbuat sejujur-jujurnya.

Para jurnalis media, Anda telah banyak berjasa dalam mencari berita dan informasi. Bagaimana kinerja jurnalis dalam suatu media berlabel Islam di Surabaya. Seorang mereka menjawab bahwa tidak mudah menjadi jurnalis yang punya semangat jihad. Mereka sering mengistikharahi sumber-sumber beritanya agar diberikan petunjuk apabila informasi yang diberikan sumber tersebut salah, kurang menjaga amanah atau kurang qualified maka segeralah ditunjukkan, lalu dibatalkan saja.

Kinerja seorang jurnalis muslim harus benar-benar selektif dalam menentukan sumber-sumber yang akan diangkat profilnya, reputasinya. Mulailah menghitung-hitung porsi dukungan kita terhadap media lebih mengarah ke mana. Apakah selama ini sudah lebih banyak mendukung media muslim atau justru malah mengabaikannya dan merasa nyaman dengan mengkonsumsi media mainstream? Kita sendiri yang tahu, kita sendiri yang mengukur, kita sendiri juga yang mampu mengubahnya, kita sendiri pula yang bisa memperbaikinya. "Jangan pernah menyesatkan audiens" kata Bill Kovach. Prinsip ini terkait erat dengan jangan menambah. Artinya, seorang jurnalis harus jujur dalam 
menyampaikan informasi kepada publik, tidak mengurangi dan tidak menambah dari informasi yang ia dapatkan.Membodohi orang adalah sebentuk kebodohan dan menghina ide jurnalisme harus berpegang teguh pada kejujuran. Jika seorang jurnalis merekonstruksi kutipan atau kejadian yang tidak disaksikan langsung, berarti audiens harus tahu kutipan tertentu tersebut hasil rekonstruksi dan bagaimana kutipan tangan kedua ini telah diverifikasi. Jika jurnalis adalah pencari kebenaran, hal ini harus diikuti dengan mereka berlaku jujur dan saksama kepada audiensi, mereka juga - bahwa mereka menjadi penyaji kebenaran. Tidak bisa tidak, tanggungjawab ini mensyaratkan jurnalis sebisa mungkin bersikap terbuka dan jujur kepada audiens mereka tentang apa yang mereka tahu dan apa yang mereka tidak tahu. "Kemanpuan wartawan untuk mengikuti nurani jauh lebih penting dari pada apapun yang mereka percayai atau keyakinan apapun yang mereka bawa ke dalam pekerjaan mereka", komentar Linda Foley, Presiden Newspaper Guild. (Bill Kovach: 2004).

Kovach dan Rosenstiel menempatkan elemen jurnalisme yang pertama adalah pada kebenaran, yang ironisnya, paling membingungkan. Kebenaran yang mana? Bukankan kebenaran bisa dipandang dari kacamata yang berbeda-beda? Tiap-tiap agama, ideologi atau filsafat punya dasar pemikiran tentang kebenaran yang belum tentu persis sama satu dengan yang lain. Sejarah pun sering direvisi. Kebenaran menurut siapa? Menurut penulis, dari kacamatan Islam, kebenaran itu sesuatu yang esensial. Jurnalis Muslim wajib menyatakan kebenaran ketika menyampaikan informasi kepada publik. Artinya berita itu harus benar dan jelas dari sumbernya, itulah esensi Islam. Jika mengabaikan kebenaran dan kejujuran, Allah SWT mengancam. "Siapa diantara mereka yang mengambil bahagian yang terbesar dalam penyiaran berita bohong itu baginya azab yang besar." (QS. An-Nuur: 12)

Dan, "kebenaran jurnalistik" ini adalah lebih dari sekedar akurasi. Prinsip pertama jurnalisme - pengejaran kebenaran tidak berat sebelah - adalah yang paling membedakannya dari semua bentuk komunikasi lain. Kebenaran yang bisa dipraktikkan ini adalah sebuah ikhwal yang bisa berubah menjadi bentuk yang berbeda, seperti halnya proses belajar, tumbuh seperti stalagmit dalam sebuah gua, setetes demi setetes seiring perjalanan waktu. Dan kebenaran jurnalistik adalah sebagai sebuah tujuan.

Jurnalis muslim dituntut berkonsentrasi pada sintesis dan verifikasi. Singkirkan desas-desus, olok-olok, hal yang tak penting, dan pelintiran. Berkonsentrasilah pada apa yang benar dan penting. Verifikasi dan sintesis menjadi tulang punggung, peran baru penjaga gerbang yang dimainkan wartawan, yaitu menjadi penyampai hal yang masuk akal, seperti yang dimaksudkan John Seeley Brown.

Andreas menganalisis, bagaimana dengan bias seorang wartawan? Tidakkah bias pandangan seorang wartawan, karena latar belakang sosial, pendidikan, kewarganegaraan, kelompok etnik, atau agamanya, bisa membuat si wartawan menghasilkan penafsiran akan kebenaran yang berbeda-beda?

Kovach dan Rosenstiel menyebutkan, masyarakat butuh prosedur dan proses guna mendapatkan apa yang disebut kebenaran fungsional. Polisi melacak dan menangkap tersangka berdasarkan kebenaran fungsional. Hakim menjalankan peradilan juga berdasarkan kebenaran fungsional. Pabrik-pabrik diatur, pajak dikumpulkan, dan hukum dibuat. Guru-guru mengajarkan sejarah, fisika, atau biologi, pada anak-anak sekolah. Semua ini adalah kebenaran fungsional. Namun, apa yang dianggap kebenaran ini senantiasa bisa direvisi. Seorang terdakwa bisa dibebaskan karena tak terbukti salah. Hakim bisa keliru. Pelajaran sejarah, fisika, biologi, bisa salah. Bahkan hukum-hukum ilmu alam pun bisa direvisi. Hal ini pula yang dilakukan jurnalisme. Bukan kebenaran dalam tataran filosofis, tapi kebenaran dalam tataran fungsional. Orang butuh informasi lalu lintas 
agar bisa mengambil rute yang lancar. Orang butuh informasi harga, kurs mata uang, ramalan cuaca, hasil pertandingan bola dan sebagainya.

Selain itu kebenaran yang diberitakan media dibentuk lapisan demi lapisan. Kovach dan Rosenstiel mengambil contoh tabrakan lalu lintas. Hari pertama seorang wartawan memberitakan kecelakaan itu. Di mana, jam berapa, jenis kendaraannya apa, nomor polisi berapa, korbannya bagaimana. Hari kedua berita itu mungkin ditanggapi oleh pihak lain. Mungkin polisi, mungkin keluarga korban. Mungkin ada koreksi. Maka pada hari ketiga, koreksi itulah yang diberitakan. Ini juga bertambah ketika ada pembaca mengirim surat pembaca, atau ada tanggapan lewat kolom opini. Demikian seterusnya.

Jadi kebenaran harus dibentuk hari demi hari, lapisan demi lapisan. Ibaratnya stalagmit (tegak), tetes demi tetes kebenaran itu membentuk stalagmit yang besar. Makan waktu, prosesnya lama. Tapi dari kebenaran sehari-hari ini pula terbentuk bangunan kebenaran yang lebih lengkap.

\section{Disiplin dalam Verifikasi.}

Disiplin mampu membuat wartawan menyaring desas-desus, gosip, ingatan yang keliru, manipulasi, guna mendapatkan informasi yang akurat. Disiplin verifikasi inilah yang membedakan jurnalisme dengan hiburan, propaganda, fiksi atau seni. Batas antara fiksi dan jurnalisme memang harus jelas. Jurnalisme tak bisa dicampuri dengan fiksi setitik pun. Kovach dan Rosenstiel mengambil contoh pengalaman Mike Wallace dari CBS yang difilmkan dalam The Insider. Film ini bercerita tentang keengganan jaringan televisi CBS menayangkan sebuah laporan tentang bagaimana industri rokok Amerika memakai zat kimia tertentu buat meningkatkan kecanduan perokok.

Kejadian itu sebuah fakta. Namun Wallace keberatan karena ada kata-kata yang diciptakan dan seolah-olah diucapkan Wallace. Sutradara Michael Mann mengatakan film itu "pada dasarnya akurat" karena Wallace memang takluk pada tekanan pabrik rokok. Jika kata-kata diciptakan atau motivasi Wallace berbeda antara keadaan nyata dan dalam film, Mann berpendapat itu bisa diterima. Kovach dan Rosenstiel mengatakan dalam kasus itu keterpaduan (utility) jadi nilai tertinggi ketimbang kebenaran harfiah. Fakta disubordinasikan kepada kepentingan fiksi. Mann membuat film itu dengan tambahan drama agar menarik perhatian penonton.

Lantas bagaimana dengan beragamnya standar jurnalisme? Tidakkah disiplin tiap wartawan dalam melakukan verifikasi bersifat personal? Kovach dan Ronsenstiel menerangkan memang tak setiap wartawan punya pemahaman yang sama. Tidak setiap wartawan tahu standar minimal verifikasi. Susahnya, karena tak dikomunikasikan dengan baik, hal ini sering menimbulkan ketidaktahuan pada banyak orang karena disiplin dalam jurnalisme ini sering terkait dengan apa yang biasa disebut sebagai objektifitas. Orang sering bertanya apa objektifitas dalam jurnalisme itu? Apakah wartawan bisa objektif? Bagaimana dengan wartawan yang punya latar belakang pendidikan, sosial, ekonomi, kewarganegaraan, etnik, agama dan pengalaman pribadi yang nilai-nilainya berbeda dengan nilai dari peristiwa yang diliputnya?

Kovach dan Rosenstiel menjelaskan, pada abad XIX tak mengenal konsep objektifitas itu. Wartawan zaman itu lebih sering memakai apa yang disebut sebagai realisme. Mereka percaya bila seorang reporter menggali fakta-fakta dan menyajikannya 
begitu saja maka kebenaran bakal muncul dengan sendirinya. Ide tentang realisme ini muncul bersamaan dengan terciptanya struktur karangan yang disebut sebagai piramida terbalik di mana fakta yang paling penting diletakkan pada awal laporan, demikian seterusnya, hingga yang paling kurang penting. Mereka berpendapat struktur itu membuat pembaca memahami berita secara alamiah.

Namun pada awal abad XX beberapa wartawan khawatir dengan naifnya realisme ini. Pada 1919 Walter Lippmann dan Charles Merz, dua wartawan terkemuka New York, menulis sebuah analisis tentang bagaimana latar belakang kultural The New York Times menimbulkan distorsi pada liputannya tentang revolusi Rusia. The New York Times lebih melaporkan tentang apa yang diharapkan pembaca ketimbang melaporkan apa yang terjadi. Lippmann menekankan, jurnalisme tak cukup hanya dilaporkan oleh "saksi mata yang tak terlatih." Niat baik atau usaha yang jujur juga tak cukup. Lippmann mengatakan inovasi baru pada zaman itu, misalnya bylines atau kolumnis, juga tidak cukup.

Bylines diciptakan agar nama setiap reporter diketahui publik yang bakal mendorong si reporter bekerja lebih baik karena namanya terpampang jelas. Kolumnis adalah wartawan atau penulis senior yang tugasnya menerangkan suatu peristiwa dengan konteks yang lebih luas yang mungkin tak bisa dilaporkan reporter yang sibuk bekerja di lapangan. Solusinya, menurut Lippmann, wartawan harus menguasai semangat ilmu pengetahuan, "There is but one kind of unity possible in a world as diverse as ours. It is unity of method, rather than aim; the unity of disciplined experiement" (Ada satu hal yang bisa disatukan dalam kehidupan yang berbeda-beda ini. Hal itu adalah keseragaman dalam mengembangkan metode, ketimbang sebagai tujuan; seragamnya metode yang ditarik dari pengalaman di lapangan)."

Baginya, metode jurnalisme bisa objektif. Tapi objektifitas ini bukanlah tujuan. Objektifitas adalah disiplin dalam melakukan verifikasi. Dengan berjalannya waktu, pemahaman orisinal terhadap objektifitas ini diartikan keliru. Banyak penulis seperti Leo Rosten, yang mengarang buku sosiologi tentang wartawan, memakai istilah objektifitas buat merujuk pada pemahaman bahwa wartawan itu seyogyanya objektif.

Kovach dan Rosenstiel menawarkan lima konsep dalam verifikasi:

1. Jangan menambah atau mengarang apa pun;

2. Jangan menipu atau menyesatkan pembaca, pemirsa, maupun pendengar;

3. Bersikaplah transparan dan sejujur mungkin tentang metode dan motivasi Anda dalam melakukan reportase;

4. Bersandarlah terutama pada reportase Anda sendiri;

5. Bersikaplah rendah hati.

Singkat kata, Kovach mengatakan, seorang wartawan "tidak mencari teman, tidak mencari musuh." Terkadang memang sulit menerima tawaran jasa baik, misalnya diantar pulang ketika kesulitan cari taksi, tapi juga tak perlu datang ke acara-acara sosial di mana independensi wartawan bisa salah dimengerti orang karena ada saja pertemanan yang terbentuk lewat acara-acara itu. "Seorang wartawan adalah mahluk asosial", kata Kovach. Asosial bukan antisosial. 


\section{Prinsip Independensi}

Kovach dan Rosenstiel berpendapat, wartawan boleh mengemukakan pendapatnya dalam kolom opini (tidak dalam berita). Kalau begitu wartawan boleh tak netral?. Menjadi netral bukanlah prinsip dasar jurnalisme. Impartialitas juga bukan yang dimaksud dengan objektifitas. Prinsipnya, wartawan harus bersikap independen terhadap orang-orang yang mereka liput. Jadi, semangat dan pikiran untuk bersikap independen ini lebih penting ketimbang netralitas. Namun wartawan yang beropini juga tetap harus menjaga akurasi dari data-datanya. Mereka harus tetap melakukan verifikasi, mengabdi pada kepentingan masyarakat, dan memenuhi berbagai ketentuan lain yang harus ditaati seorang wartawan.

Wartawan yang menulis kolom memang punya sudut pandangnya sendiri. Tapi mereka tetap harus menghargai fakta di atas segalanya," kata Anthony Lewis, kolumnis The New York Times. Menulis kolom ibaratnya, menurut Maggie Galagher dari Universal Press Syndicate, "bicara dengan seseorang yang tak setuju dengan saya." Tapi wartawan yang menulis opini tetap tidak diharapkan menulis tentang sesuatu dan ikut jadi pemain. Ini membuat si wartawan lebih sulit untuk melihat dengan perspektif yang berbeda. Lebih sulit untuk mendapatkan kepercayaan dari pihak lain. Lebih sulit lagi menyakinkan masyarakat bahwa si wartawan meletakkan kepentingan mereka lebih dulu ketimbang kepentingan kelompok di mana si wartawan ikut bermain.

Kesetiaan pada kebenaran inilah yang membedakan wartawan dengan juru penerangan atau propaganda. Kebebasan berpendapat ada pada setiap orang. Tiap orang boleh bicara apa saja walau isinya propaganda atau menyebarkan kebencian. Tapi jurnalisme dan komunikasi bukan hal yang sama. Independensi ini juga yang harus dijunjung tinggi di atas identitas lain seorang wartawan. Latar belakang etnik, agama, ideologi, atau kelas, ini seyogyanya dijadikan bahan informasi buat liputan mereka. Tapi bukan dijadikan alasan untuk mendikte si wartawan. Kovach dan Rosenstiel juga percaya, ruang redaksi yang multikultural bakal menciptakan lingkungan yang lebih bermutu secara intelektual ketimbang yang seragam. Bersama-sama wartawan dari berbagai latar ini menciptakan liputan yang lebih kaya. Tapi sebaliknya, keberagaman ini tak bisa diperlakukan sebagai tujuan. Dia adalah metode buat menghasilkan liputan yang baik.

Gil Thelan, redaktur eksekutif Tampa Tribune berpendapat, wartawan adalah orang yang "saling bergantung" dengan kebutuhan sesama warga. Jika ada masalah penting di kota yang membutuhkan pemecahan dan sedang dieksplorasi oleh lembaga-lembaga setempat, "kami punya sebuah komitmen untuk melaporkan proses ini dalam jangka panjang, sebagai seorang pengamat." Menjadi tidak bertanggungjawab meliput masalah tersebut secara serampangan - atau mengabaikannya karena itu terlihat bodoh. Wartawan dituntut setia untuk membantu memecahkan masalah, kata Thelan, dan caranya adalah menjalankan peran sebagai wartawan yang bertanggungjawab. (Bill Kovach, Elemenelemen Jurnalisme). Statement Thelan, seorang wartawan harus cukup pintar dan cukup jujur untuk mengenali bahwa opini tersebut harus berdasarkan pada sesuatu yang lebih substansial dari keyakinan pribadi jika hal ini digunakan untuk kepentingan jurnalisme. "Ini bukanlah percaya kepada orang atau kelompok orang. Ini adalah sebuah profesi yang berdasarkan reportase, proses belajar, pemahaman, dan pendidikan. Pentingnya independensi ini menjadi kian jelas saat kita menyimak kewajiban khusus jurnalisme. 


\section{KESIMPULAN}

Seorang jurnalis dinilai oleh perusahaan pers karena faktor kinerja dan prestasi. Ketika seorang wartawan mulai bekerja dengan status golongan rendah biasanya ia akan dibekali dengan tugas-tugas peliputan. Media tempat ia bekerja akan menilai kinerja wartawan tersebut sebagai dasar promosi mereka. Tidak boleh ada jurnalis muslim yang melakukan rekayasa terhadap kebenaran!. Itu saja sebenarnya belum cukup, perlu juga diantara media-media memiliki para jurnalis yang memegang teguh prinsip keimanan dan ketakwaan. Ada semangat jihad yang menggelora dalam jiwanya untuk menyampaikan apa yang disebut sebagai kebenaran. Tanpa rekayasa. Tanpa kepentingan. Tanpa kepentingan politik tertentu. Tanpa niat lain selain karena Allah SWT menyuruhnya berbuat sejujurjujurnya. Untuk mengapresiasi seorang jurnalis, tentunya perusahaan pers tetap menggunakan beberapa aspek penilaian. Setiap perusahaan memiliki kreteria penilaian sendiri-sendiri. Tapi secara sederhana, perusahaan menggunakan dua aspek besar penilaian yaitu teknik peliputan dan sikap. Salah satu aspek yang bisa memudahkan, penulis berusaha membahas tentang penilaian yang terkait dengan teknik peliputan terlebih dahulu. Seorang redaktur akan menilai laporan wartawan dari beberapa aspek yaitu kelengkapan, penulisan, deadline, daya tembus sumber berita dan akurasi Berita

Profesionalisme jurnalis tidak bisa ditawar-tawar lagi karena bisa menimbulkan efek besar jika dikesampingkan. Wartawan dan media pers bisa digugat oleh pihak yang merasa dirugikan oleh pemberitaan media tersebut. Namun dengan adanya kualifikasi dan uji kompetensi yang dilakukan oleh organisasi wartawan, diharapkan bisa memberikan perlindungan dengan menguji kemampuan profesionalnya.

Bagian terpenting dari profesi jurnalis adalah bisa berkomunikasi dengan baik, dan mampu menjaga kode etik jurnalistik. Komunikasi yang baik perlu dilakukan oleh jurnalis agar tercapai komunikasi massa yang baik pula. Komunikasi massa adalah penyebaran informasi atau berita yang dilakukan kelompok sosial tertentu kepada khalayak yang heterogen serta tersebar di mana-mana. Dalam hal ini jurnalis melakukan komunikasi massa lewat media massa baik cetak ataupun elektronik.

\section{SARAN}

Dari paparan yang telah diuraikan penulis perlu memberikan saran; seorang jurnalis tidak hanya mampu mencari dan mendapatkan berita, tetapi juga harus dapat menulis dengan baik, jujur dan proporsional. Lakukanlah riset dan banyak membaca untuk menambah wawasan adalah jalan bagi seorang jurnalis untuk mengasah kemampuan menulisnya.

\section{DAFTAR PUSTAKA}

\section{Al-Qur'anul Karim}

Ahmad Y. Samantho, Jurnalistik Islam Panduan Praktis Bagi Para Aktivis Muslim, Cet. Ke. I, Jakarta Selatan, Penerbit Harakah, 2002.

Departemen Agama RI, Proyek Penggandaan Kitab Suci Al-Qur'an, Al-Qur'an dan Tafsirnya, jilid XI, juz 29, Jakarta: YPPA, 1995.

Departemen Pendidikan Nasional, Kamus Besar Bahasa Indonesia, Cet. Ke-1, ed.Ke-3, Jakarta: Balai Pustaka, 2002. 
Herbert Strentz, Reporter dan Sumber Berita, Cet. Ke-1, Jakarta: Gramedia Pustaka Utama, 1993.

Husnun N Djuraid, Panduan Menulis Berita, Cet. Ke-2, Malang: UMM Press, 2007.

Maskun Iskandar, Panduan Jurnalistik Praktis, Cet. Ke1I, Jakarta: Lembaga Pers Dr. Sutomo, 2004.

Septiawan Santana K, Jurnalisme Investigasi, Cet. Ke-2, Jakarta: Yayasan Obor Indonesia, 2004.

Septiawan Santana K, Jurnalisme Kontemporer, Cet. Ke-1, Jakarta: Yayasan Obor Indonesia, 2005.

Suf Kasman, Jurnalisme Universal, Menelusuri Prinsip-prinsip Dakwah Bi Al-Qalam dalam Al-Qur'an, Cet. Ke-1, Jakarta: Teraju Khazanah Keilmuan, 2004.

Bill Kovach dan Tom Rosenstiel, Elemen-elemen Jurnalisme, Apa yang Seharusnya Diketahui Wartawan dan yang Diharapkan Publik, Cet. Ke. II, Jakarta, Institut Studi Arus Informasi dan Kedutaan Besar Amerika Serikat di Jakarta. 